Article

\title{
Investigating Air-Cathode Microbial Fuel Cells Performance under Different Serially and Parallelly Connected Configurations
}

\author{
Mariagiovanna Minutillo ${ }^{1,2}, * \mathbb{E}$, Simona Di Micco ${ }^{3}$, Paolo Di Giorgio ${ }^{3}$, Giovanni Erme ${ }^{4}$ and Elio Jannelli ${ }^{2,3}$ \\ 1 Department of Industrial Engineering, University of Salerno, Via Giovanni Paolo II, 132, \\ 84084 Fisciano, SA, Italy \\ 2 ATENA Future Technology, Via V. Visconti, 77, 80147 Naples, NA, Italy; elio.jannelli@uniparthenope.it \\ 3 Centro Direzionale, Department of Engineering, University of Naples "Parthenope", Isola C4, \\ 80143 Naples, NA, Italy; simona.dimicco@studenti.uniparthenope.it (S.D.M.); \\ paolo.digiorgio@uniparthenope.it (P.D.G.) \\ 4 Department of Civil and Mechanical Engineering, University of Cassino and Southern Lazio, \\ Via G. Di Biasio 43, 03043 Cassino, FR, Italy; g.erme@unicas.it \\ * Correspondence: mminutillo@unisa.it
}

check for updates

Citation: Minutillo, M.; Di Micco, S.; Di Giorgio, P.; Erme, G.; Jannelli, E. Investigating Air-Cathode Microbial Fuel Cells Performance under Different Serially and Parallelly Connected Configurations. Energies 2021, 14, 5116. https://doi.org/ 10.3390/en14165116

Academic Editors: George Avgouropoulos and Nicu Bizon

Received: 8 July 2021

Accepted: 16 August 2021

Published: 19 August 2021

Publisher's Note: MDPI stays neutral with regard to jurisdictional claims in published maps and institutional affiliations.

Copyright: (c) 2021 by the authors. Licensee MDPI, Basel, Switzerland. This article is an open access article distributed under the terms and conditions of the Creative Commons Attribution (CC BY) license (https:/ / creativecommons.org/licenses/by/ $4.0 /)$.

\begin{abstract}
Microbial fuel cells (MFCs) have recently attracted more attention in the context of sustainable energy production. They can be considered as a future solution for the treatment of organic wastes and the production of bioelectricity. However, the low output voltage and the low produced electricity limit their applications as energy supply systems. The scaling up of MFCs both by developing bigger reactors with multiple electrodes and by connecting several cells in stacked configurations is a valid solution for improving these performances. In this paper, the scaling up of a single air-cathode microbial fuel cell with an internal volume of $28 \mathrm{~mL}$, has been studied to estimate how its performance can be improved $\left(1523 \mathrm{~mW} / \mathrm{m}^{3}\right.$, at $\left.0.139 \mathrm{~mA}\right)$. Four stacked configurations and a multi-electrode unit have been designed, developed, and tested. The stacked MFCs consist of 4 reactors $(28 \mathrm{~mL} \times 4)$ that are connected in series, parallel, series/parallel, and parallel/series modes. The multi-electrode unit consists of a bigger reactor $(253 \mathrm{~mL})$ with 4 anodes and 4 cathodes. The performance analysis has point ed out that the multi-electrode configuration shows the lowest performances in terms of volumetric power density equal to $471 \mathrm{~mW} / \mathrm{m}^{3}$ at $0.345 \mathrm{~mA}$ and volumetric energy density of $624.2 \mathrm{Wh} / \mathrm{m}^{3}$. The stacked parallel/series configuration assures both the highest volumetric power density, equal to $2451 \mathrm{~mW} / \mathrm{m}^{3}(274.6 \mu \mathrm{W})$ at $0.524 \mathrm{~mA}$ and the highest volumetric energy density, equal to $2742.0 \mathrm{Wh} / \mathrm{m}^{3}$. These results allow affirming that to increase the electric power output of MFCs, the stacked configuration is the optimal strategy from designing point of view.
\end{abstract}

Keywords: microbial fuel cell; scaling up; stacked configurations; volumetric power density; series and parallel connection modes

\section{Introduction}

MFCs can be considered as a future option for the treatment of organic wastes, bioremediation, and the recovery of bioenergy from wastes [1-4]. MFCs employ exoelectrogen microorganisms to transform energy stored in the chemical bonds of organic compounds (as fuel) into electrical energy, catalyzing oxidation and reduction reactions in the area between two electrodes. The low voltage output is the main disadvantage of the MFC technology, which limits its use as electricity supply system and its success on the market of the renewable energy technologies. In order to overcome this critical factor, solutions towards the MFCs scaling-up must be investigated.

Walter et al. [5] studied the potential of scaling up a self-stratifying MFC operating in supercapacitive mode. They tested cells with different electrodes area (from $6 \mathrm{~cm}^{2}$ to 
$12 \mathrm{~cm}^{2}$ and $18 \mathrm{~cm}^{2}$ ) and reactor volumes of $49 \mathrm{~mL}, 68 \mathrm{~mL}$, and $88 \mathrm{~mL}$. Organic molecules in the hydrolyzed urine were used as anodic substrate. The authors noticed that the large size electrodes displayed the lowest power density $\left(460 \mu \mathrm{W} / \mathrm{cm}^{2}\right)$ whilst the small and medium size electrodes showed higher densities $\left(668 \mu \mathrm{W} / \mathrm{cm}^{2}\right.$ and $633 \mu \mathrm{W} / \mathrm{cm}^{2}$, respectively). Regarding the volumetric power densities, the small, the medium and the large had similar values $264 \mu \mathrm{W} / \mathrm{mL}, 265 \mu \mathrm{W} / \mathrm{mL}$ and $249 \mu \mathrm{W} \mathrm{mW} / \mathrm{mL}$, respectively.

Liu et al. [6] compared the performance of a small MFC to that of a larger one realized with a relatively higher anode surface area and a reduced electrode spacing. The small MFC produced $14 \mathrm{~W} / \mathrm{m}^{3}$ with an electrode spacing of $4 \mathrm{~cm}$, while the large MFC produced $16 \mathrm{~W} / \mathrm{m}^{3}$ with a lower average electrode spacing $(2.6 \mathrm{~cm})$ and a higher anode surface area per volume. The main results of this study were that the power output was substantially not changed during reactor scale-up and that the electrode spacing was a key design factor in maximizing power generation.

Ahn and Logan [7] studied the scaling up of microbial fuel cells by developing a compact reactor with multiple graphite fiber brush anodes and a single air-cathode cathode chamber. The maximum voltage produced in fed-batch operation was $0.65 \mathrm{~V}(1000 \Omega)$ and the maximum power density was $975 \mathrm{~mW} / \mathrm{m}^{2}$.

The development of small MFC modules integrated in stacked configurations is an efficient strategy for increasing the power output. In this case the integration of MFCs can be carried out by using different electrical connection modes: (a) the series connection, that allows to increase the voltage while one common current flows through the cells; (b) the parallel connection, that allows to increase the current output while the voltage output does not increase; (c) mixed series and parallel connections.

Aelterman et al. [8] proposed six individual continuous MFC units in a stacked configuration with electrical connections in series and parallel modes. The authors demonstrated that the maximum volumetric power outputs were unaffected by the series or parallel connection $\left(228 \mathrm{~W} / \mathrm{m}^{3}\right.$ and $248 \mathrm{~W} / \mathrm{m}^{3}$, respectively) and that an individual MFC was able to produce a higher averaged power output (until to $275 \mathrm{~W} / \mathrm{m}^{3}$ ); however, the stacked configurations allowed producing an averaged power at higher voltages and currents. Wu et al. [9] proposed a pilot-scale stacked MFCs consisting of three anode chambers and three biocathode chambers (the total volume was $72 \mathrm{~L}$ ) separated by cation exchange membranes (CEMs). Synthetic wastewater was fed into the anode chambers. They tested the stacked MFCs in fed-batch operation, measuring a maximum power density of $50.9 \mathrm{~W} / \mathrm{m}^{3}$, as well as in continuous operation in which the volumetric power density was $42.1 \mathrm{~W} / \mathrm{m}^{3}$.

Estrada-Arriaga et al. [10] proposed, two different air-cathode stacked microbial fuel cells configurations under continuous flow for municipal wastewater treatment and electricity generation. The cells were connected in series. The first stack, formed by 20 individual air-cathode MFCs, was able to produce a maximum power density of $79 \pm 0.65 \mathrm{~mW} / \mathrm{m}^{2}$ (the current density was $1.3 \pm 0.4 \mathrm{~mA} / \mathrm{m}^{2}$ ); the second stack, consisted of 40 air-cathode MFCs, was characterized by a power production of $4.2 \pm 0.6 \mathrm{~mW} / \mathrm{m}^{2}$ (the current density was $0.04 \pm 0.006 \mathrm{~mA} / \mathrm{m}^{2}$ ).

Tominaga et al. [11] evaluated the effect of the connection type in series and parallel between the anode and cathode on the power generation of MFCs that used the mud (MMFC) for assuring the anaerobic condition of the anode. A carbon felt $(5 \times 5 \mathrm{~cm})$ was used for the anode; it was placed at bottom of a square-shaped vessel $(20 \times 10 \times 6 \mathrm{~cm})$ filled with sea sediment up to $6 \mathrm{~cm}$ from the bottom. A bigger carbon felt $(10 \times 10 \mathrm{~cm})$ as cathode was placed in the electrolyte solution. By applying different external resistance, the power densities were measured. The series configuration produced $40 \mathrm{~mW} / \mathrm{m}^{2}$ and the parallel configuration was able to generate $80 \mathrm{~mW} / \mathrm{m}^{2}$.

Jafary et al. [12] proposed series and parallel configurations of stacked MFCs fed by using glucose, fructose, and sucrose. The single-cell consisted of a double chamber reactor in which the working volume of each chamber (anode and cathode chambers) was $600 \mathrm{~mL}$. The electrodes, realized in graphite felt $(80 \times 45 \times 2 \mathrm{~mm})$ were separated by a proton exchange membrane $\left(9 \mathrm{~cm}^{2}\right)$. The experimental activities showed that the highest power 
density was achieved by using the parallel configuration $\left(128 \mathrm{~mW} / \mathrm{m}^{2}\right)$ in comparison with the series one $\left(109 \mathrm{~mW} / \mathrm{m}^{2}\right)$.

Zhao et al. [13] studied a self-stacked submersible microbial fuel cell (SSMFC) powered by glycerol. The cells were connected in series and in parallel modes. The working volume (total volume was $1000 \mathrm{~mL}$ ) of the anaerobic reactor was $500 \mathrm{~mL}$. The wastewater amended with $1000 \mathrm{mg} / \mathrm{L}$ glycerol was fed into the reactor to enrich the anodic microorganism. The anode was made of non-wet-proofed plain carbon paper $\left(9 \mathrm{~cm}^{2}\right)$. The cathode chamber was open to the air through the plastic tube. Results highlighted that the maximum power density (normalized by the projected surface area of the anode) of the series connection was $488 \mathrm{~mW} / \mathrm{m}^{2}$ and that of the parallel connection was $450 \mathrm{~mW} / \mathrm{m}^{2}$.

Ieropulos et al. [14] studied the polarization curves trends of 10 identical MFCs connected in series, parallel, and series/parallel configurations (pairs of MFCs in series and the 5 pairs in parallel). Results of this study highlighted that volumetric power densities were $0.45 \mathrm{~W} / \mathrm{m}^{3}, 0.81 \mathrm{~W} / \mathrm{m}^{3}, 0.56 \mathrm{~W} / \mathrm{m}^{3}$ for the above-mentioned configurations, respectively. The authors observed that the series configuration was mainly affected by ohmic losses and the parallel one suffered from low levels of activation losses.

Vilajeliu-Pons et al. [15], proposed MFCs stacked configurations in which the cells consisted of six anodic and cathodic compartments $(90 \times 40 \times 1.5 \mathrm{~cm}$ each one $)$ hydraulically connected to an external nitrifying reactor $(150 \mathrm{~cm} \times 20 \mathrm{~cm}$ diameter $)$ and with a total volume of 65 liters. The anode and cathode compartments were separated by an anionic exchange membrane and the cells were fed by the swine manure. The authors evaluated the performances of the stacked MFCs fed by swine manure in series, parallel and mixed connections obtaining $0.03 \mathrm{~W} / \mathrm{m}^{3}, 0.27 \mathrm{~W} / \mathrm{m}^{3}$, and $0.33 \mathrm{~W} / \mathrm{m}^{3}$, respectively.

Yuvraj and Aranganathan [16] presented a study by examining the behavior of stacked microbial fuel cells for treating brewery waste effluent by using a standard glucose media. The single cell consisted of a dual-chambered reactor with a working volume of $50 \mathrm{~mL}$ for each chamber and two graphite blocks (a surface area of $0.0015 \mathrm{~m}^{2}$ ) were used as electrodes. The stacked MFCs, connected in series, parallel, and series-parallel were able to produce a power density of $813 \mathrm{~mW} / \mathrm{m}^{2}, 1546.5 \mathrm{~mW} / \mathrm{m}^{2}$, and $2418 \mathrm{~mW} / \mathrm{m}^{2}$, respectively. The best performance was obtained by the series-parallel setup arrangement underlining the interest in finding the best electrical connections for reaching combining stable and high-power outputs for practical applications.

The study published by Wang et al. [17] was the only paper in which 4 electrical connections (series, parallel, series/parallel, and parallel/series) were analyzed. The authors wanted to propose the series-parallel stack mode, as an alternative approach to series and parallel stacks to enhance the output of both voltage and current. The tested MFCs consisted of the two-chambered reactors (Plexi-glass) in which the anodic and cathodic chambers (the working volume of each chamber was $125 \mathrm{~mL}$ ) were separated by a cation exchange membrane; both the electrodes were prepared with graphite felt and their surface areas were $16 \mathrm{~cm}^{2}$. Results, in terms of power outputs $(\mathrm{mW})$ were $4.02( \pm 1.01), 6.84( \pm 0.24), 4.58( \pm 0.30)$, and $5.64( \pm 0.96)$ for the series (6 cells), parallel ( 5 cells), series / parallel (5 cells) and parallel/series ( 5 cells) connections, respectively.

Thus, by analyzing the technical literature, it can be noticed that several papers were focused on the increase in voltage and current outputs with series and parallel stacks. These studies highlighted the advantages and disadvantages of these configurations. Otherwise, few studies were devoted to evaluating the behavior of mixed solutions like series/parallel or parallel/series that could overcome some of their disadvantages.

Therefore, this paper aims to contribute to the knowledge of mixed series and parallel configurations that can represent the most interesting solutions in the scaling up MFCs.

Thus, this paper is focused on the analysis and the comparison of the performance of all possible electrical connections in terms of volumetric power density (normalized with respect to the total volume of reactors) and electric power production. Four stacked MFCs configurations have been designed, realized, and tested. Moreover, a multi-electrode 
configuration, as an alternative solution for realizing the scale-up of MFCs, has been tested too and compared to the others.

Results allowed us to find the best configuration that satisfies the increase in the power output as required for suppling sensors or other devices.

\section{Materials and Methods}

Before starting the experimental activities, an accurate procedure based on the design and development of reactors, the substrate preparation, the biofilm growth, and the bacteria acclimation, has been carried out.

\subsection{Reactors Design and Development}

The scaling up of MFCs has regarded the development of both stacked MFCs configurations and a multi-electrode reactor.

The stacked MFCs consist of 4 reactors operating in batch mode $(28 \mathrm{~mL} \times 4)$ connected in series, parallel, series/parallel, and parallel/series modes. The reactors are fluidically isolated, i.e., fed from individual lines. Each MFC shows a cubic shape with an internal volume of $28 \mathrm{~mL}$. It has been realized by using the Poly-Lactic Acid (PLA)-based material, which represents a good solution in terms of sustainability as it is not toxic for microorganisms and is completely recyclable. A 3D printer (Delta Wasp $20 \times 40$ ), based on the FDM (Fused Deposition Modeling) technique, has been employed for manufacturing the reactors. The $3 \mathrm{D}$ printer consists of a mobile nozzle with a hot end that melts the material while setting it down on a flat plate, so that the construction process is obtained by adding thin layers one by one [18]. This additive process ensures that no waste is produced and very complex shapes can be obtained with high precision $(5 \mu \mathrm{m})$ in a short time. The 3D printer requires a GCODE file as input that is generated by using the open-source software CURA (Ultimaker, Framingham, MA, USA).

Figure 1 a shows the reactor designed by using the CAD support and realized with the $3 \mathrm{D}$ printer. In the front side of the reactor, there is a hole for the cathode positioning; the anode is put orthogonally to the cathode on the opposite side. Moreover, on the upper side, a $10 \mathrm{~mm}$ circular hole is realized for the substrate inoculation. Table 1 summarizes the main geometric details of the reactor.

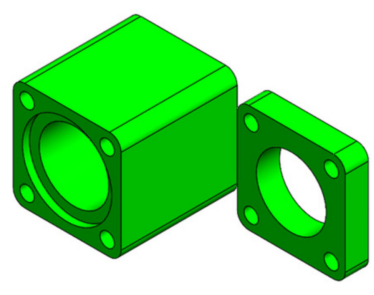

(a)

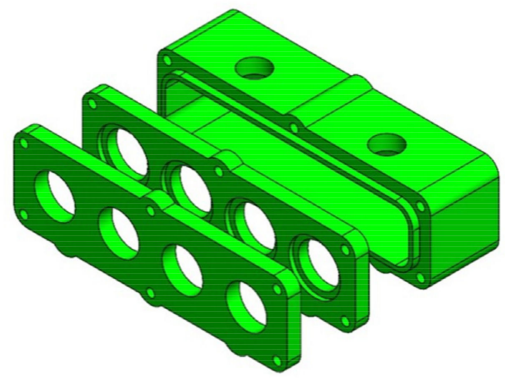

(b)

Figure 1. Reactors design: (a) Single chamber reactor, (b) multi-electrode reactor.

Table 1. Geometric data of a single-chamber MFC.

\begin{tabular}{ccc}
\hline Geometric Details & Units & Values \\
\hline External Dimensions & $\mathrm{mm}$ & $50 \times 50 \times 46.5$ \\
Internal Dimensions & $\mathrm{mm}$ & $30 \times 40$ \\
Internal Dimensions (diameter) & $\mathrm{mm}$ & 30 \\
Total internal volume & $\mathrm{mL}$ & 28 \\
Cathode surface & $\mathrm{cm}^{2}$ & 7 \\
\hline
\end{tabular}


Figure $1 \mathrm{~b}$ shows the CAD design of the multi-electrode reactor. On the front side of the reactor, there are 4 holes for the cathode positioning; 4 anodes are put orthogonally on the cathode on the opposite side. Moreover, on the upper side, two $20 \mathrm{~mm}$ circular holes for substrate inoculation are realized. Table 2 summarizes the main geometric details of this reactor.

Table 2. Geometric data of a multi-electrode MFC.

\begin{tabular}{ccc}
\hline Geometric Details & Units & Values \\
\hline External Dimensions & $\mathrm{mm}$ & $200 \times 60 \times 40$ \\
Internal Dimensions & $\mathrm{mm}$ & $179 \times 49 \times 29$ \\
Total internal volume & $\mathrm{mL}$ & 253 \\
Cathode surface & $\mathrm{cm}^{2}$ & 28 \\
\hline
\end{tabular}

A carbon fiber brush and activated carbon coated with both a PTFE (polytetrafluoroethylene) layer and a nickel mesh (as a current collector) have been selected as the anodic and cathodic electrodes, respectively [19]. The anode size is $25 \mathrm{~mm}$ in diameter and $50 \mathrm{~mm}$ in length, each carbon fiber has a diameter of $7.2 \mu \mathrm{m}$ and is fixed on titanium wires (the fiber brush is made by Mill-Rose); based on the mass of fibers used in a single brush and on the fiber diameter, Logan et al. [20] estimated a surface area of $0.22 \mathrm{~m}^{2}$. Figure 2 illustrates the anode and cathode electrodes. They have been chosen because are characterized by high conductivity, large surface area, high porosity, good biocompatibility.

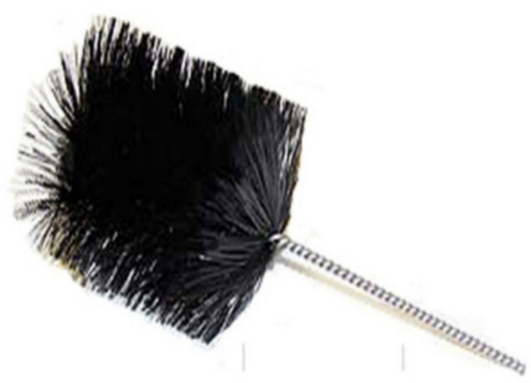

(a)

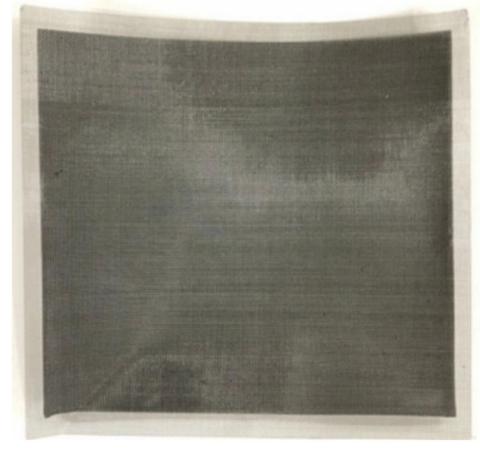

(b)

Figure 2. Selected electrodes: (a) Anodic electrode, (b) and cathodic electrode.

\subsection{Substrate Preparation}

Different types of organic substrates can be used for producing electricity: acetate, glucose, cellulose, zootechnical waste, cysteine, brewery waste, and organic fraction of municipal solid wastes. The substrate selected in this study consists of a mixture containing $50 \mathrm{~mL}$ of sodium acetate $1 \mathrm{M}$, Compost (from organic wastes), and a mineral solution prepared as suggested in ref. [21]. Sodium acetate has been chosen since provides the highest energy yield to sustain exo-electrogenic bacteria metabolism if compared to fermentable compounds like glucose, lactose, starch, and sucrose [20]. The substrate's pH is checked to always assure values in the range of $7-8$ (the $\mathrm{pH}$ affects the growth of microorganisms). The $\mathrm{pH}$ monitoring is very important because low values with respect to the neutral condition cause problems to the catabolic activities of anaerobic bacteria.

\subsection{Biofilm Development and Bacteria Acclimation}

The biofilm consists of endogenous bacterial species of the Compost, which generally are Bacillus, Geobacillus, and Brevibacillus [22-24]. The biofilm growth on the anodic electrode and the bacteria acclimation under a specified voltage difference is realized by applying a procedure consisting of 4 steps: 
i. Anode pretreatment: the anode is pretreated by soaking it into $0.5 \mathrm{M}$ hydrochloric acid for $3 \mathrm{~h}$; then the anode is rinsed with distilled water, as to suggest in ref. [20].

ii. Anode incubation: the anode is incubated for 30 days at $30{ }^{\circ} \mathrm{C}$ in a solution consisting of Compost and sodium acetate.

iii. Reactor assembly: the reactor is assembled by accurately inserting the electrodes and filled with the prepared substrate (OCV condition); for assuring that the MFCs work in anaerobic conditions, the substrate must cover completely the anode.

iv. OCV and acclimation: the reactor is kept in OCV condition for $48 \mathrm{~h}$ before starting with the acclimation phase, in which different resistances, in the range 2200-33,000 $\Omega$, are applied during a period of about 10-15 days. Before changing the resistance, the $\mathrm{OCV}$ is monitored and measured. This phase will conclude when the OCV will reach a value higher than $550 \mathrm{mV}$. This procedure allows to "train" the electrogenic bacteria in releasing the electrons to the anode and to work effectively under different voltages conditions. Results of the acclimation phase on the single cell are summarized in Table 3.

Table 3. Results of the acclimation phase on the single cell.

\begin{tabular}{ccccccccccccc}
\hline Resistance $(\Omega)$ & \multicolumn{4}{c}{$\mathbf{3 3 , 0 0 0}$} & \multicolumn{1}{c}{$\mathbf{1 0 , 0 0 0}$} & \multicolumn{2}{c}{$\mathbf{5 6 0 0}$} & \multicolumn{2}{c}{$\mathbf{2 2 0 0}$} \\
\hline Days & 1 & 2 & 3 & 4 & 5 & 6 & 7 & 8 & 9 & 10 & 11 & 12 \\
\hline Average voltage $(\mathrm{mV})$ & 163 & 236 & 245 & 314 & 238 & 196 & 250 & 266 & 276 & 326 & 210 & 215 \\
OCV $(\mathrm{mV})$ & 231 & - & - & 390 & - & - & - & 428 & & 507 & 564 \\
\hline
\end{tabular}

The electrochemical behavior of the biofilm on the electrode has been characterized by using Cyclic Voltammetry (CV). It has been performed by means of AUTOLAB system model PGSTAT204 (Metrohm Autolab) with an Ag/ AgCl as reference electrode $(+0.200 \mathrm{~V})$ and with a scan rate of $2.5 \mathrm{mV} / \mathrm{s}$. Figure 3 depicts the $\mathrm{CV}$ shape and a consequence of the biofilm activity; it can be noticed redox peaks at $-0.04 \mathrm{~V}$ and $-0.86 \mathrm{~V}$. The anode CV parameters were a start potential at $1 \mathrm{~V}$, a stopping potential at $0.2 \mathrm{~V}$.

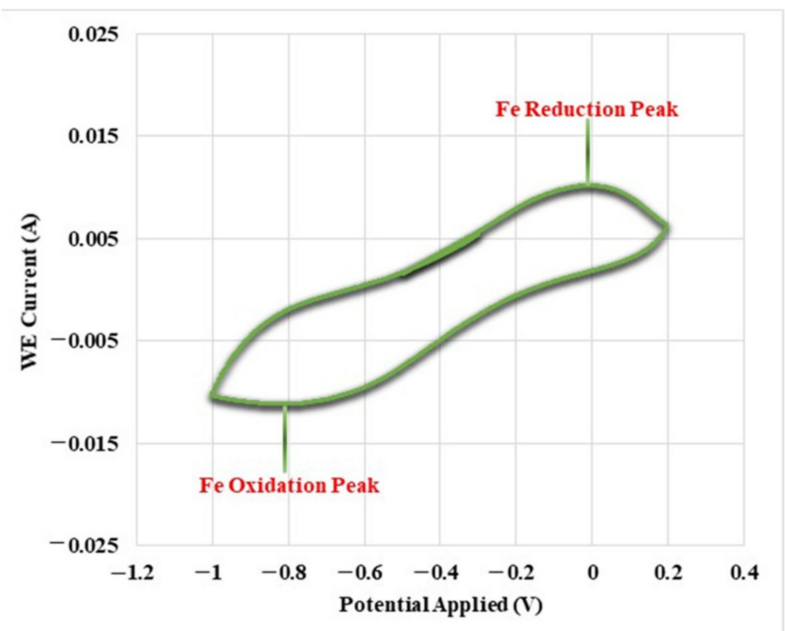

Figure 3. Anodes Cyclic Voltammetry details with Fe redox peaks.

\section{MFC Configurations}

The configurations that have been designed, developed, realized, and tested in this study are detailed as follows. 


\subsection{In Series Connected Stack}

The first electrical connection pattern is related to the series-based configuration, as shown in Figure 4. This configuration allows having an increase in the output voltage (with respect to the single-cell) that is, theoretically, equal to the sum of four voltages.

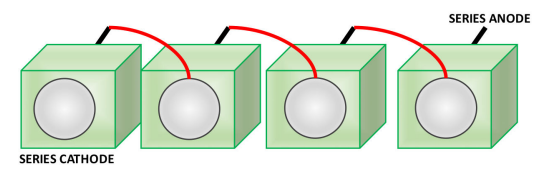

(a)

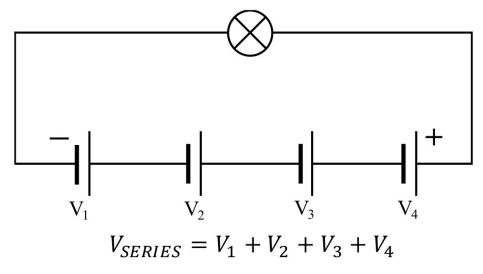

(b)

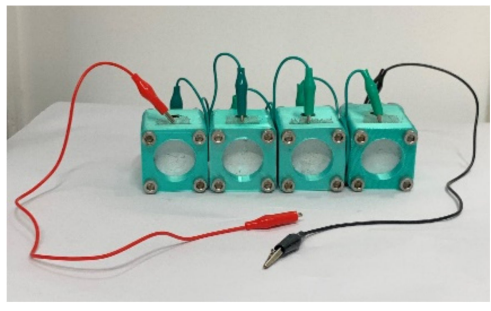

(c)

Figure 4. Series-based configuration: (a) scheme, (b) electrical connection mode and (c) stacked MFCs tested in lab.

\subsection{In Parallel Connected Stack}

The second MFCs connection pattern is related to the parallel-based configuration. This configuration allows increasing the current output (with respect to the single-cell) that is, theoretically, equal to the sum of four currents. Figure 5 shows the electrical connection and a picture of this configuration.

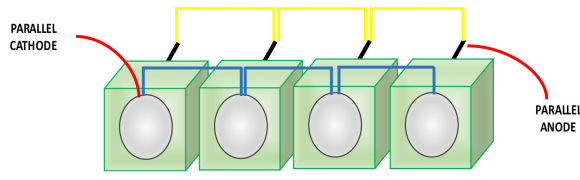

(a)

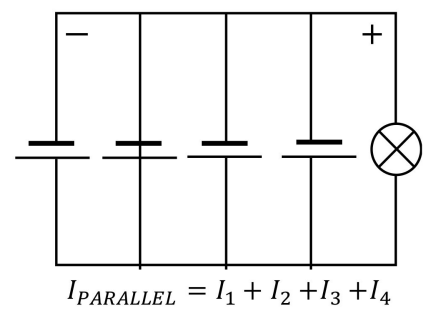

(b)

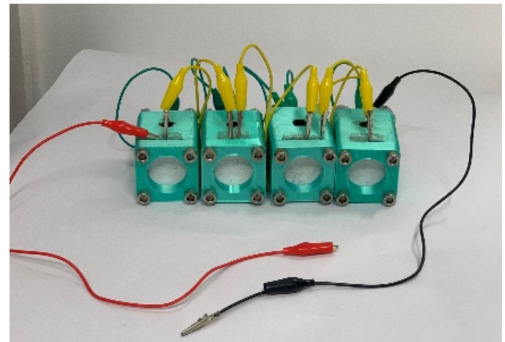

(c)

Figure 5. Parallel-based configuration: (a) scheme, (b) electrical connection mode and (c) stacked MFCs tested in lab.

\subsection{In Series/Parallel Connected Stack}

Figure 6 depicts the stacked MFCs connection pattern related to the series/parallelbased configuration. In this case, 2 MFCs have been connected in series and two series connections have been connected in parallel mode. This configuration allows achieving a higher output voltage as well as an output current compared to a single cell.

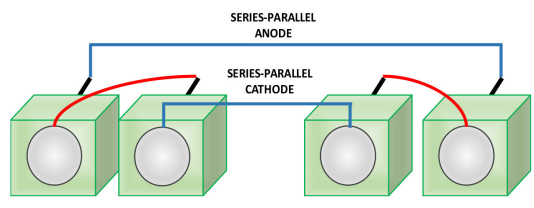

(a)

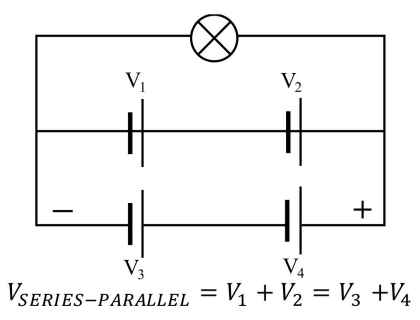

(b)

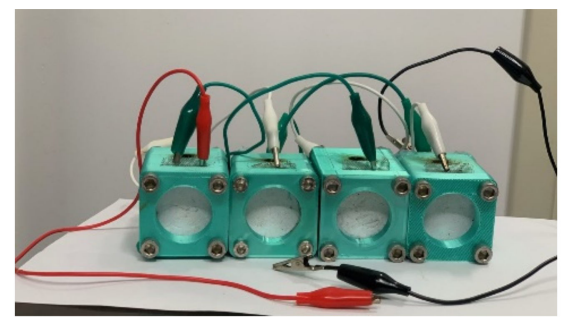

(c)

Figure 6. Series/parallel-based configuration: (a) scheme, (b) electrical connection mode and (c) stacked MFCs tested in lab. 


\subsection{In Parallel/Series Connected Stack}

The last stacked MFCs connection pattern regards the parallel/series-based configuration. In this case, 2 MFCs have been connected in parallel mode and two parallel connections have been connected in series mode (Figure 7). In this case, the output current, as well as the output voltage, are increased compared to values of a single cell.

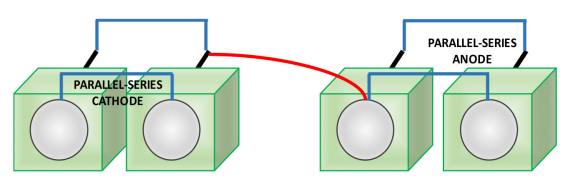

(a)

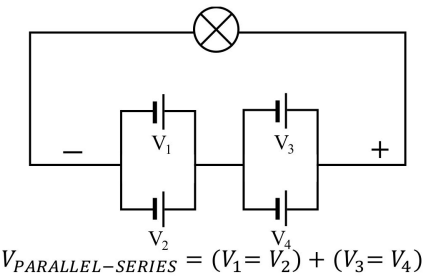

(b)

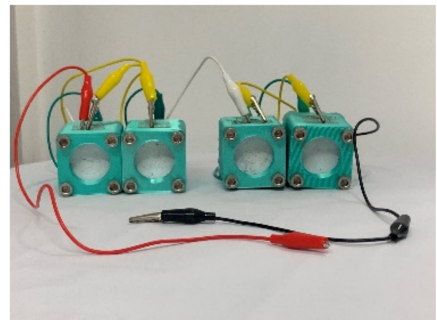

(c)

Figure 7. Parallel/series-based configuration: (a) scheme, (b) electrical connection mode and (c) stacked MFCs tested in lab.

\subsection{Multi-Electrode MFC Configuration}

The single-chamber multi-electrode reactor (Figure 8) consists of 4 anodes and 4 cathodes. From an electrical point of view, the electrodes are connected in parallel mode.

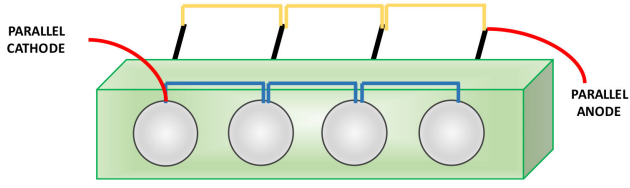

(a)

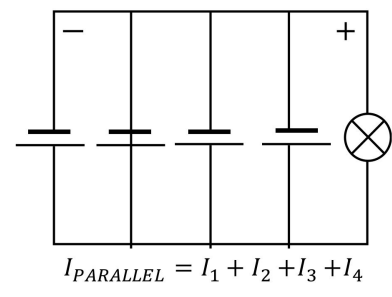

(b)

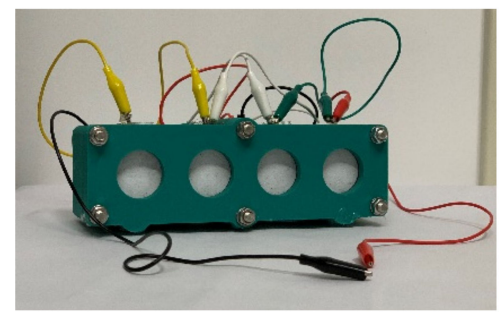

(c)

Figure 8. Multi-electrode MFC configuration: (a) scheme, (b) electrical connection mode and (c) multi-electrode MFC tested in lab.

\section{MFC Testing Procedure}

To compare the performances of the proposed MFCs configurations, the experimental activity has been organized into three tests:

- Test 1: the polarization curves for each configuration have been performed at the end of the acclimation phase; tests have been carried out according to the monocyclic method reported in ref. [25], which consists of applying decreasing resistances every $5 \mathrm{~min}$ and measuring the average output voltage.

- Test 2: the polarization curves have been measured at the end of the "quiescent timing" in which the MFCs are kept quiescent for $72 \mathrm{~h}$ until a stable OCV is achieved [26,27]; then the measurements have been carried out by applying the monocyclic method [25].

- $\quad$ Test 3: the electric energy production $(\mu \mathrm{Wh})$ has been estimated by measuring the electricity produced over time by applying a fixed external resistance; in particular, this resistance, which is different for each configuration, refers to that at which the maximum electric power is achieved.

\section{Results}

The first step of the experimental activities campaign has been to estimate the performance of the single cell. Figure 9 shows the polarization curve and the volumetric power densities measured for the single MFC. The volumetric power density has been calculated 
considering the MFC internal volume of the cell equal to $28 \mathrm{~mL}$. The operating ranges of the average voltages and currents are $0.2-0.58 \mathrm{~V}$ and $0.02-0.2 \mathrm{~mA}$, respectively. In Figure 9, standard deviations are also illustrated. It is worth noticing that the maximum average volumetric power density is $1523 \mathrm{~mW} / \mathrm{m}^{3}(42.6 \mu \mathrm{W})$ at $0.139 \mathrm{~mA}$.

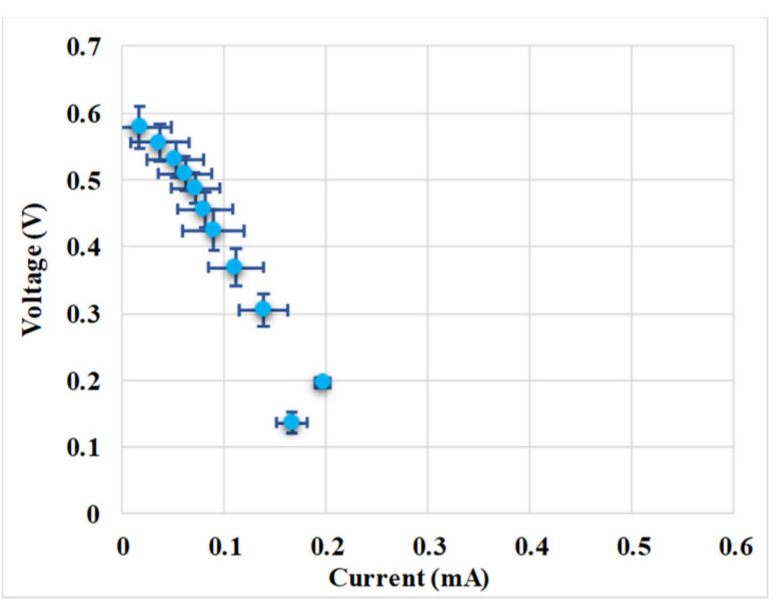

(a)

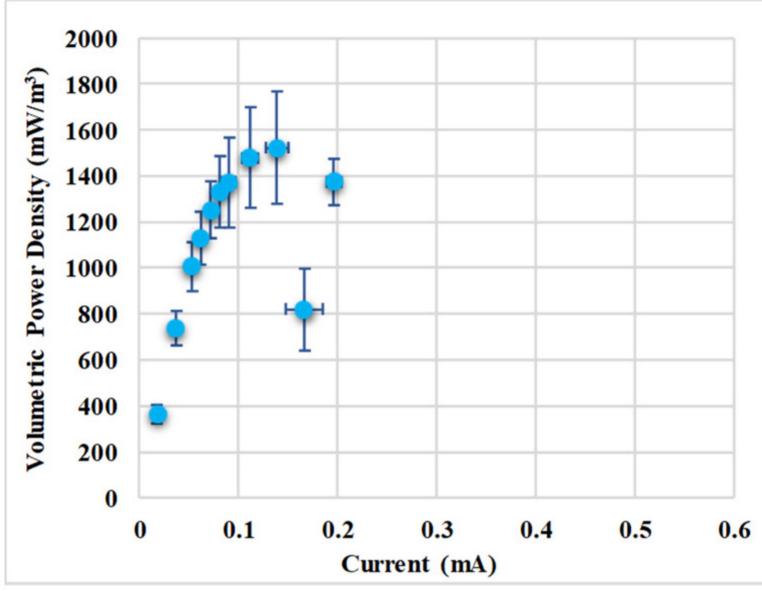

(b)

Figure 9. Single MFC performance: Polarization curve (a), volumetric power density curve (b).

Moreover, it is worth noting that at high current densities the "power overshoot" occurs. This phenomenon refers to a "doubling back" effect of the power density curve in which a lower power than that measured for lower current densities is measured [26]. According to the technical literature, the power overshoot is due to the increase in internal resistance and to the bacteria (on the anode) that are unable to produce sufficient current at lower voltages [28]. The performance of the single cell has been compared to those obtained testing all configurations.

\subsection{TEST 1}

Results of Test 1 , in terms of polarization curves and volumetric power density, are illustrated in Figure 10 where the comparison among all configurations is reported.

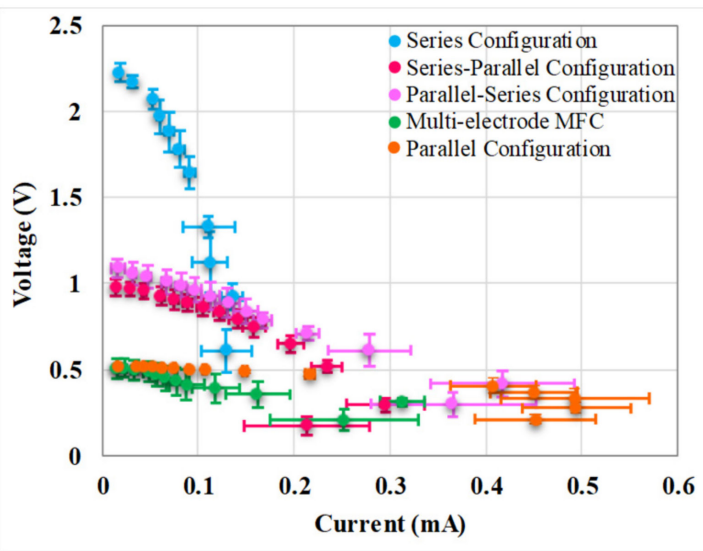

(a)

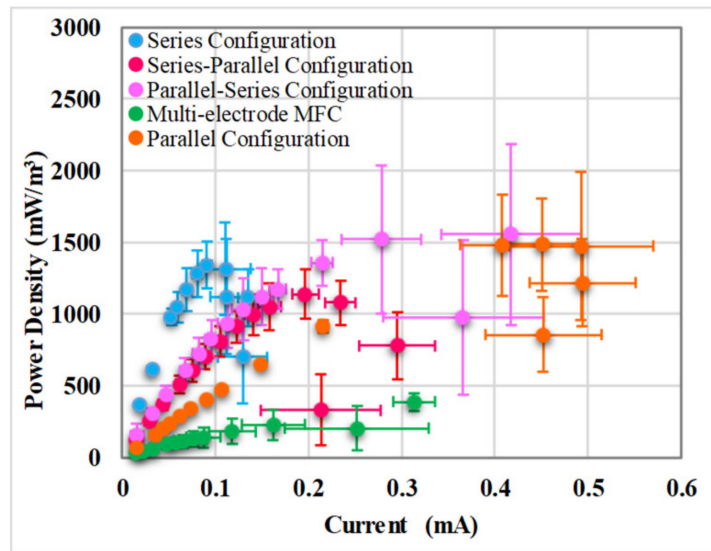

(b)

Figure 10. Test 1 results: polarization curves (a) and volumetric power density curves (b). The calculated standard deviations of the maximum power densities are equal to $\pm 323.04, \pm 514.53, \pm 170.74, \pm 633.05$, and \pm 88.63 for the series, parallel, series/parallel, parallel/series, and multi-electrode configurations, respectively. 
It can be observed that, as expected, the series-based configuration has the highest voltage operating range (up to $2.2 \mathrm{~V}$ ) and the parallel-based configuration has the highest current operating range (up to $0.5 \mathrm{~mA}$ ). The best performance in terms of volumetric power density is obtained by the parallel/series-based configuration, which can produce $1556 \mathrm{~mW} / \mathrm{m}^{3}(174.3 \mu \mathrm{W})$, at $0.418 \mathrm{~mA}$ (by applying an external resistance of $1 \mathrm{k} \Omega$ ), and by the parallel-based configuration that generates a volumetric power density of $1473 \mathrm{~mW} / \mathrm{m}^{3}$ $(165.0 \mu \mathrm{W})$ at $0.492 \mathrm{~mA}$, by applying an external resistance of $680 \Omega$. The series-based configuration shows a higher volumetric power density $\left(1342 \mathrm{~mW} / \mathrm{m}^{3}, 150.3 \mu \mathrm{W}\right)$, applying an external resistance of $18 \mathrm{k} \Omega$, compared to the series/parallel-based one $\left(1138 \mathrm{~mW} / \mathrm{m}^{3}\right.$, $127.4 \mu \mathrm{W}$ ), applying an external resistance of $3.3 \mathrm{k} \Omega$, even if this value is achieved at a lower current (0.091 vs. $0.197 \mathrm{~mA})$. The multi-electrode configuration shows the worst performance; it produces a maximum volumetric power density equal to $388 \mathrm{~mW} / \mathrm{m}^{3}$ $(98 \mu \mathrm{W})$ at $0.313 \mathrm{~mA}$ (the external resistance is equal to $1 \mathrm{k} \Omega$ ).

It is worth noticing that during TEST 1 the "power overshoot" occurs for each analyzed configuration. Because this phenomenon is mainly due to the increase in the internal resistance, it has been calculated as suggested by refs. [14,29]. Results of this analysis are summarized in Table 4, where the calculated internal resistances and the current outputs, at which the power overshoots occur by applying lower external resistances, are illustrated.

Table 4. Power overshoots conditions.

\begin{tabular}{cccc}
\hline Configuration & $\begin{array}{c}\text { External Resistance } \\
(\boldsymbol{\Omega})\end{array}$ & $\begin{array}{c}\text { Current } \\
(\mathbf{m A})\end{array}$ & $\begin{array}{c}\text { Internal Resistance } \\
(\boldsymbol{\Omega})\end{array}$ \\
\hline Series & 4700 & 0.129 & 19,400 \\
Parallel & 470 & 0.452 & 1200 \\
Parallel-Series & 820 & 0.366 & 3000 \\
Series-Parallel & 820 & 0.213 & 4600 \\
Multi-electrode & 820 & 0.252 & 2100 \\
\hline
\end{tabular}

\subsection{TEST 2}

Test 2 started after the "quiescent timing" during which the MFCs have been set in the OCV condition. Results, in terms of polarization curves and volumetric power density, are illustrated in Figure 11.

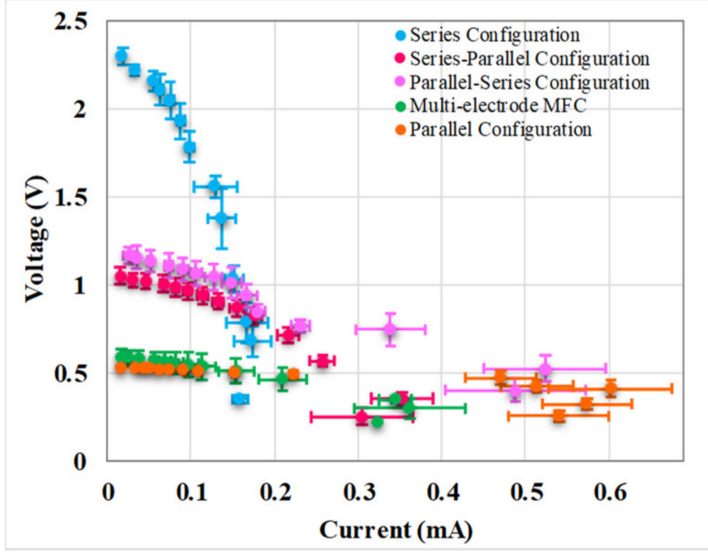

(a)

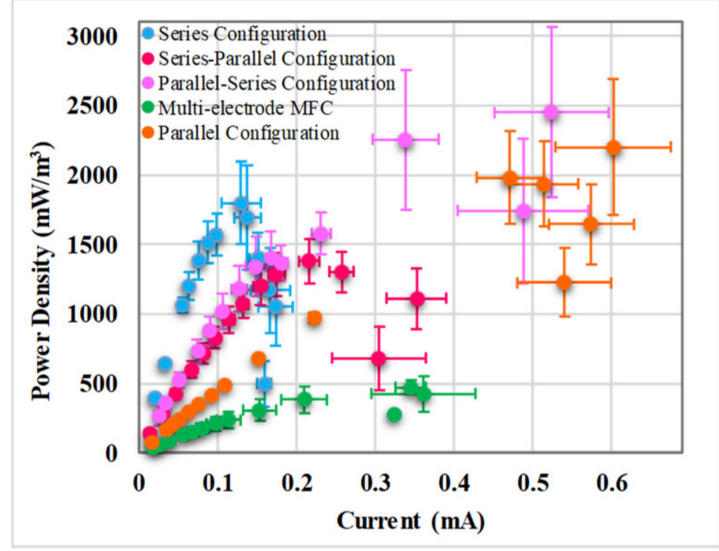

(b)

Figure 11. Test 2 results: polarization curves (a) and volumetric power density curves (b). The calculated standard deviations of the maximum power densities are equal to $\pm 301.13, \pm 490.03, \pm 158.24, \pm 612.12$, and \pm 75.34 for the series, parallel, series/parallel, parallel/series, and multi-electrode configurations, respectively. 
It can be affirmed that the performances improved in terms of volumetric power density and current operating range in all tested configurations, confirming the positive effect of the "quiescent timing" procedure that has allowed to bacteria of restoring the equilibrium between metabolic and replicative activities.

The parallel/series configuration reaches a power density of $2451 \mathrm{~mW} / \mathrm{m}^{3}(274.6 \mu \mathrm{W})$ at $0.524 \mathrm{~mA}$ (the external resistance is $1 \mathrm{k} \Omega$ ).

The parallel-based configuration increases its current operating range up to $0.602 \mathrm{~mA}$. Its volumetric power density is $2201 \mathrm{~mW} / \mathrm{m}^{3}(246.5 \mu \mathrm{W})$, by applying an external resistance of $680 \Omega$. The maximum volumetric power densities of the series-based and series/parallelbased configurations are $1799 \mathrm{~mW} / \mathrm{m}^{3}$ with an external resistance of $12 \mathrm{k} \Omega(201.5 \mu \mathrm{W})$ and $1379 \mathrm{~mW} / \mathrm{m}^{3}$ with an external resistance of $3.3 \mathrm{k} \Omega(154.5 \mu \mathrm{W})$, respectively. Finally, the multi-electrode MFC configuration increases its performance compared to Test 1 even if its behavior is the worst $\left(471 \mathrm{~mW} / \mathrm{m}^{3}\right.$ and $119.2 \mu \mathrm{W}$ and $0.345 \mathrm{~mA}$, by applying an external resistance of $1 \mathrm{k} \Omega$ ).

The power overshoots occur also during TEST 2 for each configuration. Table 5 summarizes the produced current outputs and the calculated internal resistances at which, by applying lower external resistance, the power overshoots occur.

Table 5. Power overshoots conditions.

\begin{tabular}{cccc}
\hline Configuration & $\begin{array}{c}\text { External Resistance } \\
(\boldsymbol{\Omega})\end{array}$ & $\begin{array}{c}\text { Current } \\
(\mathbf{m A})\end{array}$ & $\begin{array}{c}\text { Internal Resistance } \\
(\boldsymbol{\Omega})\end{array}$ \\
\hline Series & 2200 & 0.159 & 14,900 \\
Parallel & 470 & 0.540 & 992 \\
Parallel-Series & 820 & 0.488 & 2800 \\
Series-Parallel & 820 & 0.305 & 3700 \\
Multi-electrode & 680 & 0.324 & 1200 \\
\hline
\end{tabular}

\subsection{TEST 3}

Test 3 has been performed to estimate the ability of all configurations in producing electric energy $(\mu \mathrm{Wh})$ for supplying small sensors (like temperature or humidity sensors). The external resistances at which the highest volumetric power densities, for each configuration, were measured during Test 2 have been applied during this test.

Results in terms of operating time up to the switch-off of all systems, maximum and minimum powers (measured during the tests), and electric energy production, are summarized in Table 6.

Table 6. Electric energy production for each configuration.

\begin{tabular}{cccccc}
\hline Configuration & $\begin{array}{c}\text { Resistance } \\
\mathbf{( k \Omega} \boldsymbol{\Omega})\end{array}$ & $\begin{array}{c}\text { Operation Time } \\
\mathbf{( h )}\end{array}$ & $\begin{array}{c}\text { Standard } \\
\text { Deviation } \mathbf{( m W )}\end{array}$ & $\begin{array}{c}\text { Electric Energy } \\
\mathbf{( m W h )}\end{array}$ & $\begin{array}{c}\text { Volumetric Energy } \\
\left.\text { Density } \mathbf{( W h} / \mathbf{m}^{\mathbf{3}}\right)\end{array}$ \\
\hline Series & 12.0 & 144 & \pm 0.71 & 206.7 & 1845.2 \\
Parallel & 0.68 & 72 & \pm 0.09 & 77.8 & 694.8 \\
Parallel-Series & 1.0 & 120 & \pm 0.39 & 307.1 & 2742.0 \\
Series-Parallel & 3.3 & 72 & \pm 0.53 & 104.7 & 934.9 \\
Multi-electrode & 1.0 & 120 & \pm 0.10 & 157.9 & 624.2 \\
\hline
\end{tabular}

It is worth noticing that the parallel/series configuration assures the highest electric energy production (307.1 MWh), working for $120 \mathrm{~h}$. The series-based configuration can operate for more time (144 h) compared to the other configurations, producing electric energy of $206.7 \mathrm{mWh}$ that is a value close to the parallel/series configuration one. The parallel-based configuration shows the worst performance $(77.8 \mathrm{mWh})$ with an operating time of $72 \mathrm{~h}$. Finally, the multi-electrode configuration can generate $157.9 \mathrm{mWh}$ with an operating time of $120 \mathrm{~h}$. 


\section{Discussion}

Figure 12 illustrates the comparison among the volumetric power densities measured during TEST 2 for the analyzed configurations.

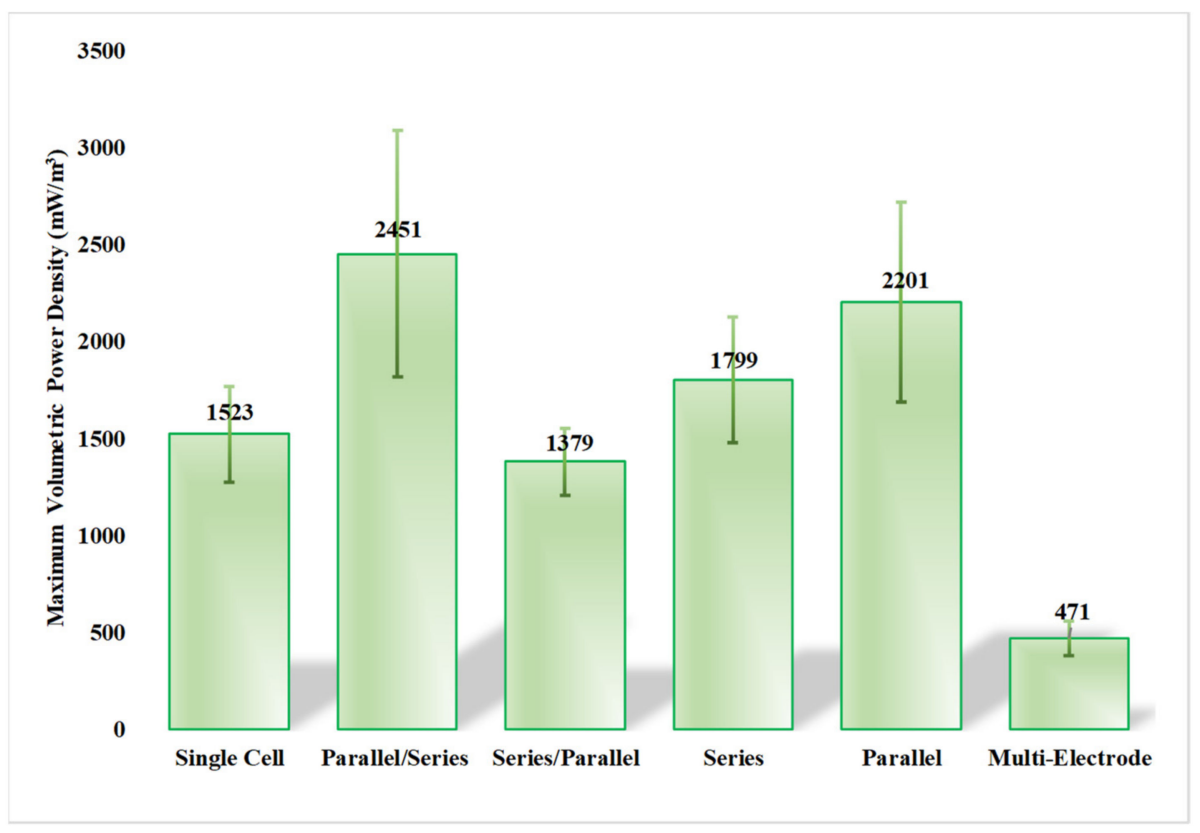

Figure 12. Comparison among the maximum volumetric power densities.

The comparison of the measured performances has highlighted that, the parallel/seriesbased configuration is the best one; it generates a maximum volumetric power density about 1.61-fold higher than that recorded from the single MFC.

This configuration is also better than the series/parallel-based one. The difference in performance could depend on the internal resistance of each cell that, in the series/parallel connection mode, causes a decrease in the output voltage with respect to the attended theoretical value. Thus, this last stacked configuration is mainly limited in power production by the ohmic losses. The series and parallel-based configurations have shown maximum volumetric power densities about 1.18-fold and 1.45-fold higher when compared to the single MFC, respectively.

The worst performance has been obtained by the multi-electrode configuration so that it is possible to conclude that the scaling up realized with a bigger reactor does not allow increasing the volumetric power density $\left(471 \mathrm{~mW} / \mathrm{m}^{3}\right)$ compared to the single cell one.

Results presented in this study have been compared to some data obtained in other studies available in the technical literature. Table 7 compares these results. It is important to underline that the mentioned papers do not deal with stacked MFCs based on the same geometric architecture, the same substrate, or the same type of biofilm, because each study developed original reactors. Thus, the comparison is presented to point out how our results are ranked with respect to the state of the art and how they concern all possible electrical connections. It can be noticed that few studies deal with parallel/series configuration, which, as illustrated in this study, represents the best solution to be implemented for increasing the power output. 
Table 7. Comparison of the performances with literature results.

\begin{tabular}{|c|c|c|c|c|c|c|c|c|c|c|}
\hline \multirow{2}{*}{$\begin{array}{c}\text { Configurations } \\
\text { Units }\end{array}$} & \multicolumn{2}{|c|}{ Multi-Electrode } & \multicolumn{2}{|c|}{ Series } & \multicolumn{2}{|c|}{ Parallel } & \multicolumn{2}{|c|}{ Series/Parallel } & \multicolumn{2}{|c|}{ Parallel/Series } \\
\hline & $\mathrm{W} / \mathrm{m}^{3}$ & $\mathrm{~W} / \mathrm{m}^{2}$ & $\mathrm{~W} / \mathrm{m}^{3}$ & $\mathrm{~W} / \mathrm{m}^{2}$ & $\mathrm{~W} / \mathrm{m}^{3}$ & $\mathrm{~W} / \mathrm{m}^{2}$ & $\mathrm{~W} / \mathrm{m}^{3}$ & $\mathrm{~W} / \mathrm{m}^{2}$ & $\mathrm{~W} / \mathrm{m}^{3}$ & $\mathrm{~W} / \mathrm{m}^{2}$ \\
\hline This work & 0.471 & 0.043 & 1.799 & 0.072 & 2.201 & 0.088 & 1.379 & 0.055 & 2.451 & 0.098 \\
\hline [7] & - & 0.975 & - & - & - & - & - & - & - & - \\
\hline [6] & 14 & - & - & - & - & - & - & - & - & - \\
\hline [10] & - & - & - & 0.079 & - & - & - & - & - & - \\
\hline [11] & - & - & - & 0.040 & - & 0.08 & - & - & - & - \\
\hline [12] & - & - & - & 0.109 & - & 0.128 & - & - & - & - \\
\hline [13] & - & - & - & 0.488 & - & 0.450 & - & - & - & - \\
\hline [14] & - & - & 0.450 & & 0.810 & & 0.560 & - & - & . \\
\hline [16] & - & - & - & 0.813 & - & 1.546 & - & 2.418 & - & - \\
\hline [15] & - & - & 0.03 & - & 0.27 & - & 0.33 & - & - & - \\
\hline [17] & - & - & 16 & - & 27.3 & - & 18.3 & - & 22.5 & - \\
\hline
\end{tabular}

\section{Conclusions}

In this study, a multi-electrode MFC and four stacked MFCs configurations, based on different electrical connection modes, have been designed, developed, realized, and tested. The multi-electrode MFC consists of 4 anodes and 4 cathodes connected in parallel mode and the stacked MFCs configurations consist of 4 MFCs connected in series, in parallel, series/parallel, and parallel/series modes.

The performance analysis has highlighted that, for all configurations, the highest volumetric power densities have been achieved after a "quiescent timing" that allowed to bacteria of restoring the equilibrium between metabolic and replicative activities. The parallel/series-based configuration showed the highest value of the measured volumetric power density while the multi-electrode MFC had the worst behavior.

Thus, the scaling-up realized by increasing the reactor's volume with multiple anodes and cathodes does not represent the optimal solution for improving the MFC power output; as a matter of fact, the negative influence of the greatest geometric parameters that involve higher ohmic losses, (i.e., the ratio between anodic and cathodic surfaces, the spacing of the electrodes, etc.), causes lower performances.

In conclusion, the stacked MFC system in parallel/series configuration represents the best solution for generating electrical power output at more practical currents and voltages, as required for supplying sensors or other devices.

Thus, even if the idea of the electrical connections for increasing the power output is not novel, as confirmed by the literature review above presented, the analyzed parallel/series connection, that resulted to be the optimal configuration, introduces an interesting novelty that can help to develop MFC power systems optimized from energy and economic points of view; as a matter of fact, considering the results obtained in this research, it is possible to affirm that, to reach the same electric power produced by the stacked MFC system in parallel/series configuration, it would be needed a higher number of reactors by using the series configuration (the most used in the scale-up of MFCs), with consequently more costs and greater overall dimensions.

Results of this study will be used for developing stacked MFCs systems based on the parallel/series configuration that will supply sensors for monitoring temperatures and humidity in real environments (from laboratory level stage to real applications).

Author Contributions: Conceptualization, M.M. and S.D.M.; methodology, M.M. and S.D.M.; validation, G.E.; formal analysis, M.M., S.D.M., P.D.G., G.E. and E.J.; investigation, M.M.; re-sources, S.D.M.; data curation, P.D.G.; writing — original draft preparation, M.M. and S.D.M.; writing—review and editing, M.M. and S.D.M.; visualization, E.J.; supervision, E.J. All authors have read and agreed to the published version of the manuscript.

Funding: This research received no external funding. 
Institutional Review Board Statement: Not applicable.

Informed Consent Statement: Not applicable.

Data Availability Statement: MDPI Research Data Policies.

Conflicts of Interest: The authors declare no conflict of interest.

\section{References}

1. Moqsud, M.A.; Omine, K.; Yasufuku, N.; Hyodo, M.; Nakata, Y. Microbial fuel cell (MFC) for bioelectricity generation from organic wastes. Waste Manag. 2013, 33, 2465-2469. [CrossRef] [PubMed]

2. Borello, D.; Gagliardi, G.; Aimola, G.; Ancona, V.; Grenni, P.; Bagnuolo, G.; Garbini, G.L.; Rolando, L.; Caracciolo, A.B. Use of microbial fuel cells for soil remediation: A preliminary study on DDE. Int. J. Hydrogen Energy 2021, 46, 10131-10142. [CrossRef]

3. Casula, E.; Kim, B.; Chesson, H.; Di Lorenzo, M.; Mascia, M. Modelling the influence of soil properties on performance and bioremediation ability of a pile of soil microbial fuel cells. Electrochim. Acta 2021, 368, 137568. [CrossRef]

4. Frattini, D.; Falcucci, G.; Minutillo, M.; Ferone, C.; Cioffi, R.; Jannelli, E. On the effect of different configurations in air-cathode MFCs fed by composite food waste for energy harvesting. Chem. Eng. Trans. 2016, 49, 85-90. [CrossRef]

5. Walter, X.A.; Santoro, C.; Greenman, J.; Ieropoulos, I. Scaling up self-stratifying supercapacitive microbial fuel cell. Int. J. Hydrogen Energy 2020, 45, 25240-25248. [CrossRef] [PubMed]

6. Liu, H.; Cheng, S.; Huang, L.; Logan, B.E. Scale-up of membrane-free single-chamber microbial fuel cells. J. Power Sources 2008, 179, 274-279. [CrossRef]

7. Ahn, Y.; Logan, B.E. A multi-electrode continuous flow microbial fuel cell with separator electrode assembly design. Appl. Microbiol. Biotechnol. 2012, 93, 2241-2248. [CrossRef]

8. Aelterman, P.; Rabaey, K.; Pham, H.T.; Boon, N.; Verstraete, W. Continuous electricity generation at high voltages and currents using stacked microbial fuel cells. Environ. Sci. Technol. 2006, 40, 3388-3394. [CrossRef]

9. Wu, S.; Li, H.; Zhou, X.; Liang, P.; Zhang, X.; Jiang, Y.; Huang, X. A novel pilot-scale stacked microbial fuel cell for efficient electricity generation and wastewater treatment. Water Res. 2016, 98, 396-403. [CrossRef] [PubMed]

10. Estrada-Arriaga, E.B.; Guillen-Alonso, Y.; Morales-Morales, C.; García-Sánchez, L.; Bahena-Bahena, E.O.; Guadarrama-Pérez, O.; Loyola-Morales, F. Performance of air-cathode stacked microbial fuel cells systems for wastewater treatment and electricity production. Water Sci. Technol. 2017, 76, 683-693. [CrossRef] [PubMed]

11. Tominaga, M.; Ototani, S.; Darmawan, R. The effect of connection type in series and parallel on electric power generation of mud microbial fuel cell. In Proceedings of the International Conference on Emerging Applications in Material Science and Technology: Iceamst 2020, Sozopol, Bulgaria, 30-31 January 2020; p. 030002. [CrossRef]

12. Jafary, T.; Rahimnejad, M.; Ghoreyshi, A.A.; Najafpour, G.; Hghparast, F.; Daud, W.R.W. Assessment of bioelectricity production in microbial fuel cells through series and parallel connections. Energy Convers. Manag. 2013, 75, 256-262. [CrossRef]

13. Zhao, N.; Angelidaki, I.; Zhang, Y. Electricity generation and microbial community in response to short-term changes in stack connection of self-stacked submersible microbial fuel cell powered by glycerol. Water Res. 2017, 109, 367-374. [CrossRef]

14. Ieropoulos, I.; Greenman, J.; Melhuish, C. Microbial fuel cells based on carbon veil electrodes: Stack configuration and scalability. Int. J. Energy Res. 2008, 32, 1228-1240. [CrossRef]

15. Vilajeliu-Pons, A.; Puig, S.; Salcedo-Dávila, I.; Balaguer, M.D.; Colprim, J. Long-term assessment of six-stacked scaled-up MFCs treating swine manure with different electrode materials. Environ. Sci. Water Res. Technol. 2017, 3, 947-959. [CrossRef]

16. Yuvraj, C.; Aranganathan, V. Configuration analysis of stacked microbial fuel cell in power enhancement and its application in wastewater treatment. Arab. J. Sci. Eng. 2017, 43, 101-108. [CrossRef]

17. Wang, Z.; Wu, Y.; Wang, L.; Zhao, F. Polarization behavior of microbial fuel cells under stack operation. Chin. Sci. Bull. 2014, 59, 2214-2220. [CrossRef]

18. Ford, S.; Despeisse, M. Additive manufacturing and sustainability: An exploratory study of the advantages and challenges. $J$. Clean. Prod. 2016, 137, 1573-1587. [CrossRef]

19. Minutillo, M.; Nastro, R.A.; Di Micco, S.; Jannelli, E.; Cioffi, R.; Di Giuseppe, M. Performance assessment of multi-electrodes reactors for scaling-up microbial fuel cells. E3S Web Conf. 2020, 197, 08020. [CrossRef]

20. Logan, B.; Cheng, S.; Watson, V.; Estadt, G. Graphite fiber brush anodes for increased power production in air-cathode microbial fuel cells. Environ. Sci. Technol. 2007, 41, 3341-3346. [CrossRef]

21. Liu, H.; Ramnarayanan, R.; Logan, B.E. Production of electricity during wastewater treatment using a single chamber microbial fuel cell. Environ. Sci. Technol. 2004, 38, 2281-2285. [CrossRef]

22. Flagiello, F.; Gambino, E.; Nastro, R.A.; Kuppam, C. Harvesting energy using compost as a source of carbon and electrogenic bacteria. In Bioelectrochemical Systems: Vol. 2 Current and Emerging Applications; Springer: Berlin/Heidelberg, Germany, 2020; Volume 2, p. 217.

23. Cercado, B.; Byrne, N.; Bertrand, M.; Pocaznoi, D.; Rimboud, M.; Achouak, W.; Bergel, A. Garden compost inoculum leads to microbial bioanodes with potential-independent characteristics. Bioresour. Technol. 2013, 134, 276-284. [CrossRef]

24. Cercado-Quezada, B.; Delia, M.-L.; Bergel, A. Treatment of dairy wastes with a microbial anode formed from garden compost. J. Appl. Electrochem. 2010, 40, 225-232. [CrossRef] 
25. Watson, V.J.; Logan, B.E. Analysis of polarization methods for elimination of power overshoot in microbial fuel cells. Electrochem. Commun. 2011, 13, 54-56. [CrossRef]

26. Khaled, F.; Ondel, O.; Allard, B. Microbial fuel cells as power supply of a low-power temperature sensor. J. Power Sources 2016, 306, 354-360. [CrossRef]

27. Chen, X.; Cui, D.; Wang, X.; Wang, X.; Li, W. Porous carbon with defined pore size as anode of microbial fuel cell. Biosens. Bioelectron. 2015, 69, 135-141. [CrossRef]

28. Kim, B.; An, J.; Chang, I.S. Elimination of power overshoot at bioanode through assistance current in microbial fuel cells. ChemSusChem 2017, 10, 612-617. [CrossRef] [PubMed]

29. Logan, B.E.; Hamelers, H.; Rozendal, R.; Schröder, U.; Keller, J.; Freguia, S.; Aelterman, P.; Verstraete, W.; Rabaey, K. Microbial fuel cells: Methodology and technology. Environ. Sci. Technol. 2006, 40, 5181-5192. [CrossRef] [PubMed] 